\title{
Common Genetic Variations Involved in the Inter-Individual Variability of Circulating Cholesterol Concentrations in Response to Diets: A Narrative Review of Recent Evidence
}

\author{
Mohammad M. H. Abdullah ${ }^{1}{ }^{\oplus}$, Itzel Vazquez-Vidal ${ }^{2}$, David J. Baer ${ }^{3}$, James D. House ${ }^{4}{ }^{\oplus}$, Peter J. H. Jones ${ }^{5}$ \\ and Charles Desmarchelier ${ }^{6, *}$ (D) \\ 1 Department of Food Science and Nutrition, Kuwait University, Kuwait City 10002, Kuwait; \\ mohamad.abdullah@ku.edu.kw \\ 2 Richardson Centre for Functional Foods \& Nutraceuticals, University of Manitoba, \\ Winnipeg, MB R3T 6C5, Canada; itzel_vazquez25@yahoo.com \\ 3 United States Department of Agriculture, Agricultural Research Service, Beltsville, MD 20705, USA; \\ david.baer@usda.gov \\ 4 Department of Food and Human Nutritional Sciences, University of Manitoba, \\ Winnipeg, MB R3T 2N2, Canada; j_house@umanitoba.ca \\ 5 Nutritional Fundamentals for Health, Vaudreuil-Dorion, QC J7V 5V5, Canada; peterjones@nfh.ca \\ 6 Aix Marseille University, INRAE, INSERM, C2VN, 13005 Marseille, France \\ * Correspondence: charles.desmarchelier@univ-amu.fr
}

Citation: Abdullah, M.M.H.; Vazquez-Vidal, I.; Baer, D.J.; House, J.D.; Jones, P.J.H.; Desmarchelier, C. Common Genetic Variations Involved in the Inter-Individual Variability of Circulating Cholesterol

Concentrations in Response to Diets: A Narrative Review of Recent Evidence. Nutrients 2021, 13, 695. https://doi.org/10.3390/nu13020695

Academic Editor:

David Cameron-Smith

Received: 31 December 2020

Accepted: 12 February 2021

Published: 22 February 2021

Publisher's Note: MDPI stays neutral with regard to jurisdictional claims in published maps and institutional affiliations.

Copyright: (c) 2021 by the authors. Licensee MDPI, Basel, Switzerland. This article is an open access article distributed under the terms and conditions of the Creative Commons Attribution (CC BY) license (https:// creativecommons.org/licenses/by/ $4.0 /)$.

\begin{abstract}
The number of nutrigenetic studies dedicated to the identification of single nucleotide polymorphisms (SNPs) modulating blood lipid profiles in response to dietary interventions has increased considerably over the last decade. However, the robustness of the evidence-based science supporting the area remains to be evaluated. The objective of this review was to present recent findings concerning the effects of interactions between SNPs in genes involved in cholesterol metabolism and transport, and dietary intakes or interventions on circulating cholesterol concentrations, which are causally involved in cardiovascular diseases and established biomarkers of cardiovascular health. We identified recent studies (2014-2020) that reported significant SNP-diet interactions in 14 cholesterol-related genes (NPC1L1, ABCA1, ABCG5, ABCG8, APOA1, APOA2, $A P O A 5, A P O B, A P O E, C E T P, C Y P 7 A 1, D H C R 7, L P L$, and $L I P C)$, and which replicated associations observed in previous studies. Some studies have also shown that combinations of SNPs could explain a higher proportion of variability in response to dietary interventions. Although some findings still need replication, including in larger and more diverse study populations, there is good evidence that some SNPs are consistently associated with differing circulating cholesterol concentrations in response to dietary interventions. These results could help clinicians provide patients with more personalized dietary recommendations, in order to lower their risk for cardiovascular disease.
\end{abstract}

Keywords: lipids; gene-diet interaction; personalized nutrition; single nucleotide polymorphism; genetic variant; cardiovascular diseases; nutrigenetics

\section{Introduction}

Personalized nutrition is the next frontier for the food and health industries. Presently, consumers report high expectations for the role proper genetic information could play in their dietary choices for the prevention and treatment of chronic diseases [1,2]. Cardiovascular disease (CVD) is still the leading cause of death globally, and it is estimated that $90 \%$ of cases are preventable, with healthy diet considered as the first line of intervention [3,4]. Lowering of blood lipid concentrations is a major target in both the primary and secondary prevention of CVD, but high interindividual variability exists in response to any given dietary intervention [5]. 
Genome-wide association studies (GWAS) have identified numerous single nucleotide polymorphisms (SNPs) that are associated with the variability of fasting blood cholesterol concentrations. These genetic variations have been estimated to explain about $30 \%$ of total variance [6,7]. Yet, the application of the results to personalized dietary recommendations is not straightforward because these studies usually do not consider the effect of diet. Several clinical trials have investigated the relationship between dietary interventions and blood lipid concentrations, considering the genetic characteristics of the participants. However, by design, they usually only focus on individual SNPs, resulting in a relatively low explained genetic variance [8,9]. A greater part of the variability in blood lipid concentrations could be explained by the additive effects of several SNPs, which, taken individually, may only have small, and barely significant, effects $[10,11]$. While numerous studies have reported SNPs that are significantly associated with blood cholesterol concentrations in response to various diets [8], there is a need to review additional data generated in this field.

The objective of this narrative review is, thus, to summarize recent findings of interactions between individual SNPs in major cholesterol-related genes and dietary intakes, relative to shaping circulating cholesterol concentrations. The review also highlights studies that used combinations of SNPs to increase the explained variability in cholesterol concentrations following dietary interventions. Looking at the sum of evidence accumulated in the field enables discussion of what is still missing in order to put this knowledge into practice.

\section{Search Process and Criteria}

For the purpose of this review, we considered only genes that are explicitly involved in cholesterol absorption, metabolism, and transport pathways (Figure 1). A systematic search was utilized, and gene-diet interaction studies relative to the genes of interest were retrieved, with no restriction on study design, dietary protocol, population, or quality throughout the preliminary search. Searches were performed on articles published between 1 January 2014 (as a follow-up to our previous review on the topic [8]) and 30 September 2020 using the MEDLINE (PubMed) database, and searching string variations of the following keywords: (diet OR gene-diet OR dietary) AND (cholesterol) AND (SNP OR polymorphism OR genetic variant). A total of 291 articles were identified and examined individually to exclude research articles that did not report statistically significant cholesterol responses to gene-diet interactions, did not present clear associations, or did not provide data details. With the exclusion of all review articles, animal studies, and articles in languages other than English, as well as those considering factors other than diet, such as physical activity, alcohol intake, smoking, and others, a total of 21 distinct research articles were eligible for inclusion in the individual SNP-diet interaction analysis (Section 3), and four articles were eligible for the combinatory patterns of SNPs analysis (Section 4) below.

The following sections present statistically significant findings regarding the effects of interactions between SNPs (taken individually or in combinatory patterns) and dietary intakes on circulating cholesterol concentrations in observational studies and dietary interventions. Nomenclature for all genes in this work is reported according to international standards of the Human Genome Organization (HUGO) [12], with description of variants at the DNA level and reference to SNPs as rs\#-xx homozygotes or rs\#-x alleles, even when authors of some of the reviewed articles reported variants as defined by their encoding amino acid changes, using the 3-letter code or the 1-letter code, with no mention of the rs\# for their SNPs. Where applicable in the sections below, the meanings of such amino acid codes are addressed. 


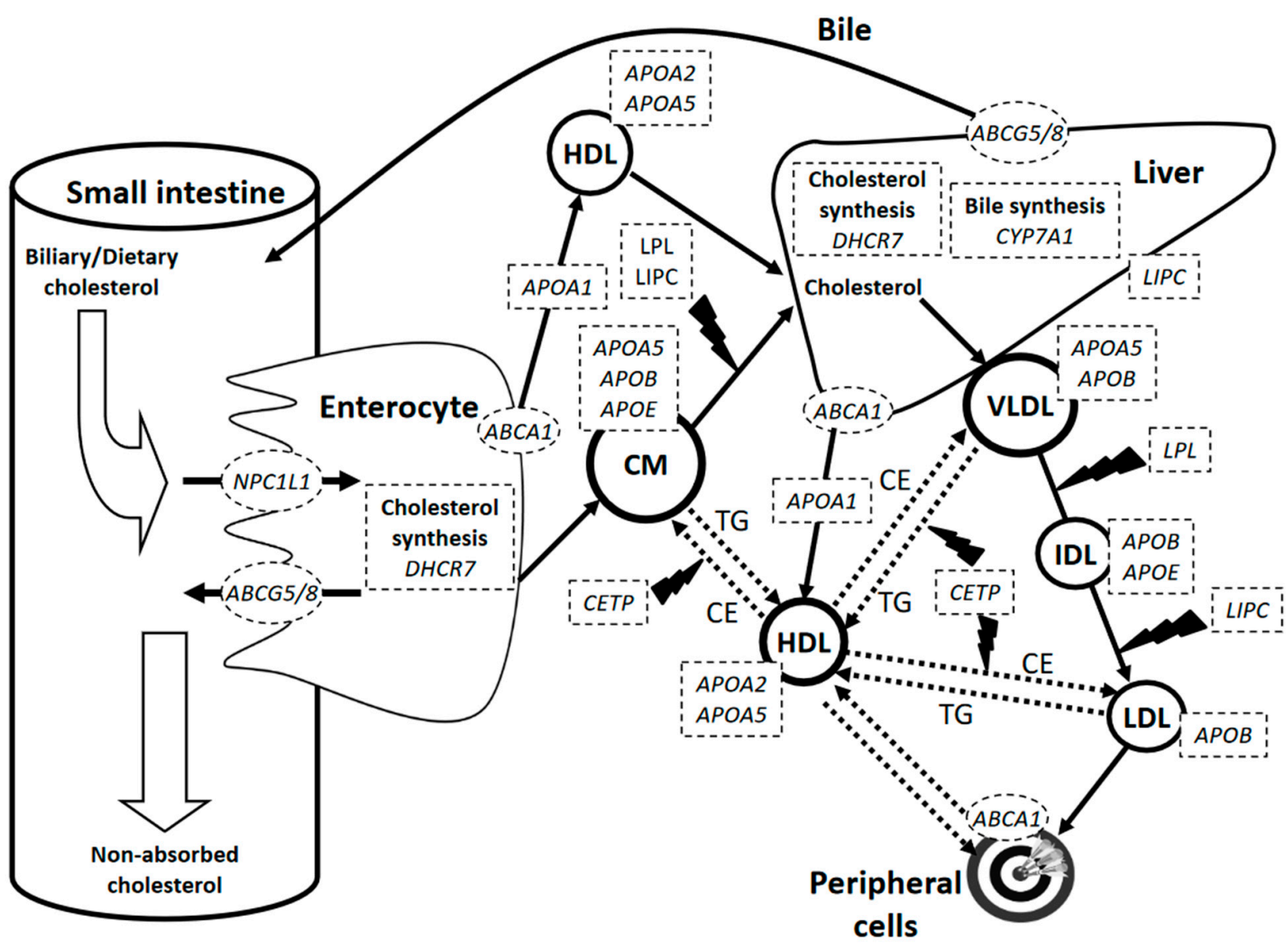

Figure 1. Summary of genes of lipid metabolism and transport pathways involved in the variability of circulating cholesterol concentrations in response to diets. Genes displayed are those for which significant SNP-diet interactions have been reported recently (2014-2020). ABCA1, ATP binding cassette subfamily A member 1; ABCG5/8, ATP binding cassette subfamily $G$ member 5/8; APOA1, apolipoprotein A1; APOA2, apolipoprotein A2; APOA5, apolipoprotein A5; APOB, apolipoprotein B; APOE, apolipoprotein E; CE, cholesteryl esters; CETP, cholesteryl ester transfer protein; CYP7A1, cholesterol 7-alpha-hydroxylase; DHCR7, 7-dehydrocholesterol reductase; HDL, high-density lipoprotein; IDL, intermediate-density lipoprotein; LDL, low-density lipoprotein; LPL, lipoprotein lipase; LIPC, hepatic lipase; NPC1L1, NPC1 like intracellular cholesterol transporter 1; TG, triglycerides; VLDL, very-low-density lipoprotein

\section{Studies Investigating the Effect of SNPs Taken Individually}

In this section, a summary of the recent evidence on statistically significant genediet interactions is presented considering individual SNP data (Table 1). This approach has been the most widely utilized in research and reported in the literature due to both technical and statistical reasons. For instance, sequencing and genotyping techniques, such as commercially available SNP assays and PCR methods, are presently low-cost and easy-to-implement. Moreover, dietary interventions are typically expensive to carry out, and usually have relatively low sample sizes, resulting in limited statistical power. Nonetheless, they allow for identification of new genetic associations based on known or predicted SNP functions. Importantly, the SNP-diet interactions identified in clinical settings also constitute good candidates for building genetic risk scores (GRS) of cumulative SNPs, aiming at predicting practical changes in biomarkers of health in response to dietary intakes. 
Table 1. Summary of epidemiological and dietary intervention studies reporting significant effects of individual SNP-diet interactions on circulating cholesterol concentrations.

\begin{tabular}{|c|c|c|c|c|c|c|}
\hline Author & Gene & SNP & Study Design & Diet & $\begin{array}{l}\text { Population and } \\
\text { Ethnicity }\end{array}$ & Major Cholesterol Outcomes \\
\hline $\begin{array}{l}\text { Jacobo-Albavera et al. } \\
\qquad \text { (2015) [13] }\end{array}$ & $A B C A 1$ & rs9282541 & Cross-sectional & Dietary $\mathrm{CHO}$ and fat intakes & $\begin{array}{l}1598 \text { premenopausal } \\
\text { females, Mexicans }\end{array}$ & $\begin{array}{c}\text { HDL-C concentrations negatively correlated } \\
\text { with CHO intake and positively correlated with } \\
\text { fat intake in T allele carriers but not CC } \\
\text { homozygotes }\end{array}$ \\
\hline Liu et al. (2014) [14] & $A B C A 1$ & rs2230806 & Dietary intervention & $\begin{array}{l}\text { 7-d of washout diet followed } \\
\text { by 6-d of high-CHO/low-fat diet }\end{array}$ & $\begin{array}{l}56 \text { healthy adults, } \\
\text { Chinese }\end{array}$ & $\begin{array}{l}\text { Lower LDL-C/HDL-C concentration ratios in A } \\
\text { allele male carriers and GG female homozygotes } \\
\text { after vs. before high-CHO/low-fat diet }\end{array}$ \\
\hline $\begin{array}{l}\text { Abdullah et al. } \\
\text { (2016) [15] }\end{array}$ & ABCG5 & rs6720173 & Crossover & Dairy vs. dairy-free diets & $\begin{array}{l}101 \text { healthy adults, } \\
\text { Canadians }\end{array}$ & $\begin{array}{c}\text { Higher TC and LDL-C concentrations in GG } \\
\text { homozygotes vs. C allele carriers after } 3 \\
\text { servings/d of dairy vs. dairy-free diets }\end{array}$ \\
\hline $\begin{array}{l}\text { Granado-Lorencio et al. } \\
\text { (2014) [16] }\end{array}$ & ABCG8 & rs6544718 & Crossover & $\begin{array}{c}750 \mu \mathrm{g} \beta \text {-cryptoxanthin and } \\
1.5 \mathrm{~g} / \mathrm{d} \text { PS, } \\
\text { single and combined }\end{array}$ & $\begin{array}{l}19 \text { postmenopausal } \\
\text { females, Spanish }\end{array}$ & $\begin{array}{c}\text { Lower TC concentrations in CC homozygotes vs. } \\
\text { T allele carriers after } \beta \text {-cryptoxanthin + PS } \\
\text { combined intake }\end{array}$ \\
\hline de Luis et al. (2018) [17] & APOA1 & rs670 & Dietary intervention & Hypocaloric diet of one arm & 82 obese adults, Spanish & $\begin{array}{c}\text { Lower HDL-C concentrations in GG } \\
\text { homozygotes vs. A allele carriers at baseline and } \\
\text { after hypocaloric diet }\end{array}$ \\
\hline de Luis et al. (2019) [18] & APOA1 & rs670 & Dietary intervention & $\begin{array}{l}\text { Hypocaloric high-fat vs. } \\
\text { low-fat diets }\end{array}$ & $\begin{array}{l}282 \text { obese adults, } \\
\text { Spanish }\end{array}$ & $\begin{array}{c}\text { Higher HDL-C concentrations in A allele carriers } \\
\text { vs. GG homozygotes at baseline and after both } \\
\text { high-fat and low-fat diets }\end{array}$ \\
\hline $\begin{array}{l}\text { Noorshahi et al. } \\
\quad \text { (2016) [19] }\end{array}$ & APOA2 & rs5082 & Cross-sectional & $\begin{array}{c}\text { Dietary SFA intake } \\
(>28.5 \mathrm{~g} / \mathrm{d}) \text {, assessed by FFQ }\end{array}$ & $\begin{array}{l}697 \text { type } 2 \text { diabetic } \\
\text { adults, Iranians }\end{array}$ & $\begin{array}{l}\text { Higher LDL-C/HDL-C concentration ratio in CC } \\
\text { homozygotes vs. T allele carriers with higher } \\
\text { SFA intake }\end{array}$ \\
\hline $\begin{array}{l}\text { Dominguez-Reyes et al. } \\
\text { (2015) [20] }\end{array}$ & APOA5 & rs662799 & Cross-sectional & $\begin{array}{l}\text { Dietary fat intake, assessed } \\
\text { by FFQ }\end{array}$ & $\begin{array}{c}200 \text { young } \\
\text { normal-weight and } \\
\text { obese adults, Mexicans }\end{array}$ & $\begin{array}{l}\text { Lower HDL-C concentrations and higher PUFA } \\
\text { intake in C allele carriers vs. TT homozygotes }\end{array}$ \\
\hline Lim et al. (2014) [21] & APOA5 & rs662799 & Cross-sectional & $\begin{array}{l}\text { Dietary intake, assessed by } \\
\text { 24-h recall and FFQ }\end{array}$ & $\begin{array}{l}1128 \text { premenopausal } \\
\text { females, Koreans }\end{array}$ & $\begin{array}{c}\text { Lower HDL-C concentrations in CC } \\
\text { homozygotes with higher total energy intake } \\
(\geq 2001 \mathrm{kcal} / \mathrm{d})\end{array}$ \\
\hline Doo et al. (2015) [22] & $A P O B$ & rs1469513 & $\begin{array}{l}\text { Cross-sectional } \\
\text { ('KoGES' Study) }\end{array}$ & $\begin{array}{c}\text { Total energy and } \\
\text { macronutrient intake, assessed } \\
\text { by FFQ }\end{array}$ & 6470 adults, Koreans & $\begin{array}{l}\text { Higher TC and LDL-C concentrations in G allele } \\
\text { carriers with higher energy or fat intake, and in } \\
\text { AA homozygotes with higher } \mathrm{CHO} \text { intake }\end{array}$ \\
\hline
\end{tabular}


Table 1. Cont.

\begin{tabular}{|c|c|c|c|c|c|c|}
\hline Author & Gene & SNP & Study Design & Diet & $\begin{array}{l}\text { Population and } \\
\text { Ethnicity }\end{array}$ & Major Cholesterol Outcomes \\
\hline Shatwan et al. (2017) [23] & $A P O E$ & rs1064725 & $\begin{array}{l}\text { 16-wk parallel dietary } \\
\text { intervention } \\
\text { ('DIVAS' Study) }\end{array}$ & $\begin{array}{l}\text { Isoenergetic diets rich in SFA, } \\
\text { MUFA, or n-6 PUFA }\end{array}$ & $\begin{array}{l}120 \text { adults with } \\
\text { moderate cardiovascular } \\
\text { risk, Caucasians }\end{array}$ & $\begin{array}{c}\text { Lower TC concentrations only in TT } \\
\text { homozygotes after MUFA-rich diet vs. SFA-rich } \\
\text { or n-6 PUFA-rich diets }\end{array}$ \\
\hline Weber et al. (2016) [24] & $A P O E$ & $\begin{array}{l}\text { rs429258 } \\
\text { rs7412 }\end{array}$ & $\begin{array}{c}\text { Cross-sectional } \\
\text { (German Diabetes Study) }\end{array}$ & $\begin{array}{l}\text { Dietary fat intake, assessed } \\
\text { by FFQ }\end{array}$ & 348 diabetics, Germans & $\begin{array}{l}\text { Lower LDL-C concentrations in } A P O E \varepsilon 2 \text { carriers } \\
\text { with lower vs. higher intake frequencies of butter, } \\
\text { cream cake, French fries, or alcoholic beverages }\end{array}$ \\
\hline Griffin et al. (2018) [26] & $A P O E$ & $\begin{array}{l}\text { rs429258 } \\
\text { rs7412 }\end{array}$ & $\begin{array}{l}\text { 24-wk five-arm parallel } \\
\text { dietary intervention } \\
\text { ('RISCK' Study) }\end{array}$ & $\begin{array}{l}\text { Replacing SFA with either } \\
\text { MUFA or carbohydrate of } \\
\text { high or low GI }\end{array}$ & $\begin{array}{l}389 \text { adults at increased } \\
\text { risk of developing MetS, } \\
\text { white Caucasians }\end{array}$ & $\begin{array}{l}\text { Greater decreases in TC concentrations in carriers } \\
\text { of E4 vs. E3/E3 when SFA was replaced with low } \\
\text { GI carbohydrate on a lower fat diet, and an } \\
\text { increase in TC concentrations when SFA was } \\
\text { replaced with MUFA and high GI carbohydrates }\end{array}$ \\
\hline $\begin{array}{l}\text { Garcia-Rios et al. } \\
\quad \text { (2016) [27] }\end{array}$ & CETP & rs3764261 & $\begin{array}{l}\text { 1-y dietary intervention } \\
\text { ('CORDIOPREV' Study) }\end{array}$ & $\begin{array}{l}\text { Mediterranean diet ( } 35 \% \text { fat, } \\
22 \% \text { MUFA) vs. low-fat diet } \\
\text { (28\% fat, } 12 \% \text { MUFA) }\end{array}$ & $\begin{array}{l}424 \text { MetS subjects, } \\
\text { Spanish }\end{array}$ & $\begin{array}{c}\text { Higher HDL-C concentrations after } \\
\text { Mediterranean diet in T allele carriers vs. } \\
\text { GG homozygotes }\end{array}$ \\
\hline $\begin{array}{l}\text { Hosseini-Esfahani et al } \\
\text { (2019) [28] }\end{array}$ & CETP & rs3764261 & $\begin{array}{l}\text { Population-based } \\
\text { prospective design } \\
\text { (Tehran Lipid and } \\
\text { Glucose Study) }\end{array}$ & $\begin{array}{l}\text { Usual dietary intake, assessed } \\
\text { by FFQ }\end{array}$ & 4700 adults, Iranians & $\begin{array}{c}\text { Lower TC concentrations and higher fish intakes } \\
\text { in T allele carriers vs. GG homozygotes after } \\
3.6 \text { years of follow-up }\end{array}$ \\
\hline $\begin{array}{l}\text { Abdullah et al. } \\
\quad(2016)[15]\end{array}$ & CYP7A1 & rs3808607 & Crossover & Dairy vs. dairy-free diets & $\begin{array}{l}101 \text { healthy adults, } \\
\text { Canadians }\end{array}$ & $\begin{array}{c}\text { Higher TC concentrations in G allele carriers vs. } \\
\text { TT homozygotes after } 3 \text { servings /d of dairy vs. } \\
\text { dairy-free diets }\end{array}$ \\
\hline Mackay et al. (2015) [25] & CYP7A1 & rs3808607 & Crossover & $2 \mathrm{~g} / \mathrm{d}$ of PS & $\begin{array}{l}\quad 63 \text { mildly } \\
\text { hypercholesterolemic } \\
\text { adults, Canadians }\end{array}$ & $\begin{array}{l}\text { Greater reduction in LDL-C concentrations after } \\
\text { PS intake in GG vs. TT homozygotes }\end{array}$ \\
\hline Wang et al. (2016) [29] & CYP7A1 & rs3808607 & Crossover & $\begin{array}{l}\text { Barley } \beta \text {-glucan vs. } \\
\quad \text { control diet }\end{array}$ & $\begin{array}{l}30 \text { mildly } \\
\text { hypercholesterolemic } \\
\text { adults, Canadians }\end{array}$ & $\begin{array}{l}\text { Lower TC concentrations after } 3 \mathrm{~g} / \mathrm{d} \text { of high } \\
\text { molecular weight barley } \beta \text {-glucan in } \mathrm{G} \text { allele } \\
\text { carriers vs. TT homozygotes }\end{array}$ \\
\hline
\end{tabular}


Table 1. Cont.

\begin{tabular}{|c|c|c|c|c|c|c|}
\hline Author & Gene & SNP & Study Design & Diet & $\begin{array}{l}\text { Population and } \\
\text { Ethnicity }\end{array}$ & Major Cholesterol Outcomes \\
\hline $\begin{array}{l}\text { Abdullah et al. } \\
\text { (2016) [15] }\end{array}$ & DHCR7 & rs760241 & Crossover & Dairy vs. dairy-free diets & $\begin{array}{l}101 \text { healthy adults, } \\
\text { Canadians }\end{array}$ & $\begin{array}{c}\text { Higher LDL-C concentrations in A allele carriers } \\
\text { vs. GG homozygotes after } 3 \text { servings/d of dairy } \\
\text { vs. dairy-free diets }\end{array}$ \\
\hline Zhu et al. (2014) [30] & $L P L$ & rs326 & Dietary intervention & $\begin{array}{l}\text { 7-d of washout diet followed } \\
\text { by 6-d of high-CHO } \\
\text { (70\% energy)/low-fat } \\
\text { ( } 14 \% \text { energy) diet }\end{array}$ & $\begin{array}{l}56 \text { healthy Chinese } \\
\text { Han youth }\end{array}$ & $\begin{array}{l}\text { Higher HDL-C concentrations in G allele male } \\
\text { carriers after vs. before high-CHO/low-fat diet }\end{array}$ \\
\hline $\begin{array}{l}\text { Ayyappa et al. } \\
\text { (2017) [31] }\end{array}$ & $L P L$ & rs1121923 & $\begin{array}{l}\text { Cross-sectional } \\
\text { (Chennai Urban Rural } \\
\text { Epidemiological Study) }\end{array}$ & $\begin{array}{l}\text { Dietary intakes, assessed } \\
\text { by FFQ }\end{array}$ & $\begin{array}{l}788 \text { type } 2 \text { diabetes cases } \\
\text { and } 1057 \text { controls, } \\
\text { Asian Indians }\end{array}$ & $\begin{array}{l}\text { Higher HDL-C concentrations in T allele carriers } \\
\text { with high fat diet vs. CC homozygotes }\end{array}$ \\
\hline Smith et al. (2017) [32] & LIPC & rs1800588 & Crossover & $\begin{array}{l}\text { Comparing a high-fat Western } \\
\text { diet and a low-fat traditional } \\
\text { Hispanic diet }\end{array}$ & $\begin{array}{l}42 \text { adults, Caribbean } \\
\text { Hispanic descent }\end{array}$ & $\begin{array}{c}\text { Higher HDL-C concentrations in CC } \\
\text { homozygotes after high-fat Western diet } \\
\text { (39\% energy) vs. low-fat traditional Hispanic diet } \\
\text { ( } 20 \% \text { energy) }\end{array}$ \\
\hline Xu et al. (2015) [33] & LIPC & rs2070895 & $\begin{array}{c}\text { 2-y randomized } \\
\text { weight-loss } \\
\text { dietary intervention } \\
\text { ('POUNDS LOST' Study) }\end{array}$ & Dietary intakes & $\begin{array}{l}743 \text { overweight or } \\
\text { obese adults, } \\
\text { multiethnic groups }\end{array}$ & $\begin{array}{l}\text { Higher TC concentrations after high fat intake, } \\
\text { and higher HDL-C concentrations after low fat } \\
\text { intake, in A allele carriers vs. GG homozygotes }\end{array}$ \\
\hline $\begin{array}{l}\text { Granado-Lorencio et al. } \\
\qquad \text { (2014) [16] }\end{array}$ & NPC1L1 & rs2072183 & Crossover & $\begin{array}{l}750 \mu \mathrm{g} \beta \text {-cryptoxanthin } \\
\text { and } 1.5 \mathrm{~g} / \mathrm{d} \mathrm{PS}, \\
\text { single and combined }\end{array}$ & $\begin{array}{l}19 \text { postmenopausal } \\
\text { females, Spanish }\end{array}$ & $\begin{array}{l}\text { Higher TC concentrations in CC homozygotes vs. } \\
\text { G allele carriers after PS intake only }\end{array}$ \\
\hline
\end{tabular}

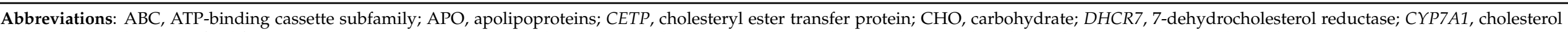

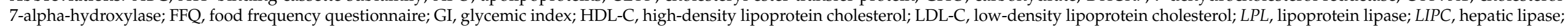

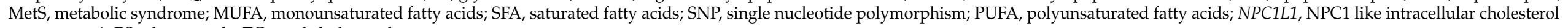
transporter 1; PS, plant sterols, TC, total cholesterol. 


\subsection{SNPs in Genes Encoding Transporters Involved in Cholesterol Absorption}

NPC1 like intracellular cholesterol transporter 1 (NPC1L1) is an apical multi-pass membrane protein that mediates the transport of sterols into enterocytes and hepatocytes through clathrin-mediated endocytosis, and is essential for cholesterol trafficking [34-36]. It is now well-established that dietary plant sterols (PS) can inhibit intestinal cholesterol absorption through several mechanisms, such as competition for incorporation into mixed micelles, hydrolysis of esters by digestive enzymes, enterocyte uptake by NPC1L1, and incorporation into chylomicrons $[34,37]$. In a randomized crossover supplementation study involving 19 post-menopausal females, participants carrying the CC genotype at rs2072183 (a synonymous variant with leucine at 272, published as L272L) in NPC1L1 showed significantly different changes in serum TC and LDL-C concentrations $(0.38 \pm 0.29$ and $0.33 \pm 0.29 \mathrm{mmol} / \mathrm{L}$, respectively) compared to carriers of the $\mathrm{G}$ allele $(-0.29 \pm 0.10$ and $-0.18 \pm 0.12 \mathrm{mmol} / \mathrm{L}$, respectively) after consuming for four weeks a beverage providing $1.5 \mathrm{~g} \mathrm{PS} / \mathrm{d}$ [16]. Of note, these differences were no longer significant when an outlier in the participants homozygous for the minor allele was excluded from the statistical analysis.

ATP-binding cassette subfamily A1 (ABCA1) is a basolateral membrane protein that transports cholesterol and phospholipids out of enterocytes and hepatocytes, which are then collected by apolipoprotein A1 (encoded by APOA1) to form nascent HDL particles [38,39]. A 2015 cross-sectional study involving 1598 premenopausal Mexican females found that serum HDL-C concentrations were negatively correlated with carbohydrate intake ( $r=-0.362)$, and positively correlated with fat intake $(r=0.357)$, in carriers of the $\mathrm{T}$ allele at rs9282541 in $A B C A 1$ (published as RC/CC in the R230C missense variant, as defined by the amino acid change) but not in those carrying the CC genotype (published as RR in $\mathrm{R} 230 \mathrm{C}$ variant) [13]. This variant is restricted to the Americas, where its presence explains up to $4 \%$ of the variation in HDL-C concentrations [40]. In an intervention study, 56 healthy Chinese adults received a washout diet where carbohydrate contributed $54 \%$ of energy for $7 \mathrm{~d}$, followed by a high-carbohydrate/low-fat diet where carbohydrate and fat contributed $70 \%$ and $14 \%$ of energy, respectively, for $6 \mathrm{~d}$ [14]. Males carrying the A (published as K) allele and females carrying the GG (published as RR) genotype at rs2230806 in $A B C A 1$ (G1051A; published as R219K, a missense variant, as defined by the amino acid change) displayed lower LDL-C/HDL-C concentration ratios (1.08 \pm 0.27 vs. $1.48 \pm 0.64$ in males, and $1.01 \pm 0.18$ vs. $1.37 \pm 0.33$ in females) after the high-carbohydrate/low-fat diet [14].

The ATP-binding cassette subfamily $\mathrm{G}$ member 5 and 8 (ABCG5/G8) genes encode two transporters (ABCG5 and ABCG8) that are responsible for the excretion of sterols by hepatocytes and enterocytes [41]. Rare and common genetic variations in ABCG5/G8 have been linked to increased intestinal absorption of cholesterol and PS [42-44]. In a 2016 randomized crossover study by our group, involving 101 normocholesterolemic adults, the $A B C G 5$ rs6720173-GG homozygotes had higher serum TC (change: $0.18 \pm 0.06$ vs. $-0.07 \pm 0.07 \mathrm{mmol} / \mathrm{L}$ ) and LDL-C (change: $0.17 \pm 0.05 \mathrm{vs}$. $-0.06 \pm 0.07 \mathrm{mmol} / \mathrm{L}$ ) concentrations relative to rs6720173-C allele carriers after three servings/d of dairy (low-fat milk, low-fat yogurt, and regular cheddar cheese) versus a dairy-free diets for 4 wk each [15]. These data replicate, to some extent, previous associations described among Spanish children [45], where male carriers of the ABCG5 rs6720173-G allele had higher plasma TC and LDL-C concentrations with a daily intake of 14.3-34.1 g saturated fatty acids (SFA) compared to CC homozygotes [45]. Another crossover multiple-dose supplementation study with beta-cryptoxanthin and PS in healthy postmenopausal females showed that carriers of the CC genotype of $A B C G 8$ rs6544718 (published as A632V, a missense variant, as defined by the amino acid change) had lower serum TC concentrations $(-0.34 \pm 0.09 \mathrm{mmol} / \mathrm{L})$ compared to carriers of the T allele $(0.08 \pm 0.20 \mathrm{mmol} / \mathrm{L})$ after consuming a beverage providing $1.5 \mathrm{~g} / \mathrm{d}$ of PS plus $750 \mu \mathrm{g}$ beta-cryptoxanthin over $4 \mathrm{wk}$ [16].

\subsection{SNPs in Genes Encoding Apolipoproteins}

Apolipoprotein A1 (APOA1) encodes a protein that drives maturation of HDL particles [46,47]. A weight loss intervention of one arm involving 82 obese patients showed that 
carriers of the GG genotype at rs670 in APOA1 had lower serum HDL-C concentrations compared to A allele carriers, both at baseline $(1.43 \pm 0.25$ vs. $1.50 \pm 0.24 \mathrm{mmol} / \mathrm{L})$ and after $12 \mathrm{wk}(1.37 \pm 0.21$ vs. $1.45 \pm 0.23 \mathrm{mmol} / \mathrm{L})$ on a hypocaloric diet (reduction of $500 \mathrm{kcal} / \mathrm{d}$ ) [17]. A similar $12 \mathrm{wk}$ hypocaloric intervention involving 282 obese participants, by the same group, reported improvements in HDL-C concentrations among the rs670-A allele carriers versus GG homozygotes at baseline, as well as after both high-fat $(1.42 \pm 0.23$ vs. $1.27 \pm 0.18 \mathrm{mmol} / \mathrm{L})$ and low-fat $(1.53 \pm 0.21$ vs. $1.40 \pm 0.23 \mathrm{mmol} / \mathrm{L})$ diets [18].

Apolipoprotein A2 (APOA2) encodes the second most common protein found in HDL particles [48]. A 2016 cross-sectional study involving 697 diabetic participants from Tehran, Iran, reported that carriers of the APOA2 rs5082-CC genotype who, based on a semiquantitative food frequency questionnaire (FFQ) analysis, had higher SFA intake ( $>28.5 \mathrm{~g} / \mathrm{d}$, considering mean SFA intake of the study population as cutoff point) and displayed a higher LDL-C/HDL-C concentration ratio (2.27 \pm 0.72 vs. $2.04 \pm 0.63)$ compared to carriers of the T allele [19].

Apolipoprotein A5 (APOA5) encodes an essential protein component of several lipoproteins such as VLDL, HDL, and chylomicrons [49]. A number of meta-analyses have demonstrated that SNPs in APOA5 may be associated with increased risk for CVD, where, in particular, carriers of the APOA5 rs662799-C allele exhibit higher concentrations of TC and TG, and lower concentrations of HDL-C compared to non-carriers [50,51]. In a cross-sectional study conducted among young Mexicans (18-25 y), participants carrying the rs662799-C allele and who traditionally consumed a diet higher in PUFAs, with median (percentile 25-75) of 10 (8-12) g/d vs. 8 (6-12) g/d also showed lower serum HDL-C concentrations compared to TT homozygotes (1.1 (0.9-1.2) mmol/L vs. $1.2(1.0-1.4) \mathrm{mmol} / \mathrm{L})$; although this was not reported by the authors as part of their gene-diet interaction data [20]. In another cross-sectional study involving 1128 premenopausal Korean females, among participants who had total energy intakes $\geq 2001 \mathrm{kcal} / \mathrm{d}$, based on a $24-\mathrm{h}$ recall method and a semi-quantitative FFQ data analysis, rs662799-CC homozygotes displayed lower serum HDL-C concentrations ( 1.16 vs. $1.42 \mathrm{mmol} / \mathrm{L})$ compared to T allele carriers [21].

Apolipoprotein $B(A P O B)$ encodes a protein that modulates the formation and blood clearance of LDL particles and triglyceride (TG)-rich lipoproteins. Circulating apoB-48 and apoB-100 concentrations are well-known biomarkers of cardiovascular health [52]. A cross-sectional study including 6470 Korean adults showed that among those who reported consuming higher levels of energy ( $\geq 1983.7 \mathrm{kcal} / \mathrm{d})$, based on a semi-quantitative FFQ analysis, carriers of the minor allele $(\mathrm{G})$ at rs1469513 in APOB had higher plasma TC $(+2.42 \%)$ and LDL-C (+1.96\%) concentrations compared to the AA homozygotes; similar TC response was seen with higher fat intake ( $\geq 19.9 \%$ energy), where the difference between $\mathrm{G}$ allele carriers and AA homozygotes was 2.04\% [22]. In contrast, homozygotes for the A allele who consumed carbohydrates in excess of $64.9 \%$ of energy exhibited higher TC $(+1.81 \%)$ and LDL-C (+2.80\%) concentrations compared to G allele carriers [22].

Apolipoprotein $\mathrm{E}$ is one of the major proteins involved in the transport of cholesterol and TG within the circulation [53]. A 2017 retrospective analysis of 120 participants enrolled in the DIVAS study, a parallel design based on a food-exchange model of SFA, monounsaturated fatty acid (MUFA), and polyunsaturated fatty acid (PUFA) intakes in free-living individuals for $16 \mathrm{wk}$, reported that only APOE rs1064725-TT homozygotes, but not $G$ allele carriers, showed a reduction in serum TC concentrations after the MUFA diet $(-0.71 \pm 1.88 \mathrm{mmol} / \mathrm{L})$ compared to the SFA $(0.34 \pm 0.55 \mathrm{mmol} / \mathrm{L})$ or $\mathrm{n}-6 \mathrm{PUFA}$ diets $(-0.08 \pm 0.73 \mathrm{mmol} / \mathrm{L})$ [23]. A German diabetes study evaluated the interaction between dietary patterns, using FFQ data, and APOE polymorphisms in 348 diabetic patients, where among carriers of the APOE $\varepsilon 2$ isoform (E2/E2, E2/E3; rs429258: TT, rs7412: TT/CT), lower versus higher consumption frequencies of butter, cream cake, French fries, or alcoholic beverages were independently associated with a $40 \%$ reduction in serum LDL-C concentrations [24]. In a randomized crossover design involving 63 mildly hypercholesterolemic individuals who consumed $2 \mathrm{~g} / \mathrm{d}$ of PS for $28 \mathrm{~d}$, carriers of the APOE $\varepsilon 4$ isoform had a greater reduction in serum LDL-C concentrations $(-0.31 \pm 0.07 \mathrm{mmol} / \mathrm{L}$ 
vs. $-0.13 \pm 0.05 \mathrm{mmol} / \mathrm{L}$ ) compared to carriers of the APOE $\varepsilon 3$ isoform [25]. This study also reported an interaction between APOE and CYP7A1-rs3808607, where participants of all genosets, except for CYP7A1-rs3808607 T/T + APOE $\varepsilon 3$, showed reductions in LDL-C concentrations in response to PS consumption [25]. Furthermore, in a secondary analysis of data from the RISCK study, a 24-wk five-arm parallel intervention involving 389 adults, carriers of E4 relative to E3/E3 showed greater decreases in plasma TC concentrations $(-0.28 \pm 0.13 \mathrm{mmol} / \mathrm{L})$ when SFA was replaced with low glycemic index (GI) carbohydrate on a lower fat diet, and a relative increase in TC concentrations $(0.30 \pm 0.14 \mathrm{mmol} / \mathrm{L})$ when SFA was replaced with MUFA and high GI carbohydrates [26].

\subsection{Genes Encoding Additional Proteins Involved in the Cholesterol Metabolic Pathway}

Cholesteryl ester transfer protein (CETP) exchanges TG from lipoproteins (VLDL or LDL) with cholesteryl esters from HDL particles [54]. In the CORDIOPREV clinical trial involving 424 Spanish participants with metabolic syndrome (MetS) who received a Mediterranean diet rich in fat from olive oil (35\% fat, $22 \%$ MUFA) or a low-fat diet (28\% fat, $12 \%$ MUFA), carriers of the minor allele (T) at rs3764261 in CETP showed higher plasma HDL-C concentrations (1.06 \pm 0.03 vs. $0.98 \pm 0.02 \mathrm{mmol} / \mathrm{L})$ compared to GG homozygotes after 1 y on the Mediterranean diet, but not after the low-fat diet [27]. The CETP rs3764261diet interaction was more recently investigated among 4700 adults from the Tehran Lipid and Glucose Study, a population-based prospective design, where among carriers of the $\mathrm{T}$ (published as A) allele, serum TC concentrations decreased from 8.02 to $5.58 \mathrm{mmol} / \mathrm{L}$ as fish intake increased from $<3.6 \mathrm{~g} / \mathrm{d}$ (quartile 1) through $>14.9 \mathrm{~g} / \mathrm{d}$ (quartile 4) compared to GG (published as CC) homozygotes, after 3.6 years of follow-up [28].

Cholesterol 7-alpha hydroxylase, encoded by CYP7A1, is a rate-limiting enzyme in the classic bile acid synthesis pathway in the liver. CYP7A1 rs3808607 has been associated with inter-individual variability in circulating cholesterol concentrations in response to dietary intakes. For instance, after $4 \mathrm{wk}$ on a crossover design with dairy versus dairy-free diets, we have previously shown that carriers of the rs3808607-G allele had higher serum TC concentrations (ranging between $0.20 \pm 0.06$ and $0.28 \pm 0.12 \mathrm{mmol} / \mathrm{L}$ for GT and GG genotypes, respectively) compared to TT homozygotes $(-0.11 \pm 0.08 \mathrm{mmol} / \mathrm{L})$ [15]. In response to PS intake, however, the rs3808607-GG homozygotes showed greater a reduction in serum LDL-C concentrations $(-0.46 \pm 0.12 \mathrm{vs}$. $-0.05 \pm 0.07 \mathrm{mmol} / \mathrm{L})$ compared to the TT homozygotes [25]. In yet another crossover design involving 30 mildly hypercholesterolemic adults who received a breakfast that contained either $3 \mathrm{~g}$ of high molecular weight barley $\beta$-glucan or a control diet daily for $5 \mathrm{wk}$ each, carriers of the rs3808607-G allele showed greater reduction in serum TC concentrations $(-0.58$ and $-0.70 \mathrm{mmol} / \mathrm{L}$ for GT and GG genotypes, respectively) compared to TT homozygotes ( $-0.31 \mathrm{mmol} / \mathrm{L})$ [29].

The 7-dehydrocholesterol reductase, encoded by DHCR7, is the enzyme that catalyzes the terminal reaction of cholesterol synthesis in the liver. In response to dairy intervention, carriers of the DHCR7 rs760241 minor allele (A) showed higher serum LDL-C concentrations $(0.26 \pm 0.08$ vs. $0.06 \pm 0.05 \mathrm{mmol} / \mathrm{L})$ relative to GG homozygotes [15]. To our knowledge, this study by members of our group was the first, and thus far only, evidence of such interaction between the DHCR7 SNP rs760241 and dietary intake.

Lipoprotein lipase, encoded by $L P L$, is an enzyme catalyzing the hydrolysis of TG from apoB-containing lipoproteins. A 2014 dietary intervention involving 56 healthy young Chinese showed that only male carriers of the LPL rs326 minor allele (G) had an increase in plasma HDL-C concentrations ( $1.32 \pm 0.27$ vs. $1.21 \pm 0.21 \mathrm{mmol} / \mathrm{L})$ after versus before a $6-\mathrm{d}$ diet of high-carbohydrate (70.1\% energy) /low-fat (13.7\% energy) [30]. In the cross-sectional Chennai Urban Rural Epidemiological Study, involving type 2 diabetes cases and controls from India, carriers of the LPL rs1121923 minor allele (T) exhibited higher serum HDL-C concentrations (1.2 vs. $1.1 \mathrm{mmol} / \mathrm{L})$ compared to CC homozygotes after consumption of a higher fat diet (3rd tertile: $28.4 \pm 2.5 \%$ energy), as assessed by a semi-quantitative FFQ [31]. No differences were observed among genotypic groups consuming a diet providing less than $23.5 \%$ of energy from fat. 
Hepatic lipase, encoded by LIPC, is an enzyme involved in reverse cholesterol transport. In a 2017 crossover, randomized controlled trial involving 42 Caribbean Hispanics, carriers of the LIPC rs1800588 major allele (C) had higher plasma HDL-C concentrations $(1.3 \pm 0.03$ vs. $1.1 \pm 0.04 \mathrm{mmol} / \mathrm{L}$ during phase 1 , and $1.4 \pm 0.03$ vs. $1.2 \pm 0.03 \mathrm{mmol} / \mathrm{L}$ during phase 2 of the trial) after consuming a high-fat Western diet (39\% energy) compared to a low-fat traditional Hispanic diet (20\% energy) for $4 \mathrm{wk}$ each, whereas no difference was observed between Western and Hispanic diets among TT homozygotes [32]. In the POUNDS LOST trial, a long-term weight-loss intervention with diets varying in macronutrient composition, overweight and obese carriers of the LIPC rs2070895 minor allele (A) showed an increase in serum TC concentrations ( $\beta \pm$ SE: $0.19 \pm 0.07 \mathrm{mmol} / \mathrm{L})$ on a high-fat diet $(40 \%$ energy) and a slight decrease in HDL-C concentrations ( $\beta \pm \mathrm{SE}:-0.04 \pm 0.02 \mathrm{mmol} / \mathrm{L})$ on a low-fat diet ( $20 \%$ energy) compared to rs2070895-GG homozygotes at $2 \mathrm{yr}$ of the intervention [33].

\section{Combinatory Patterns of SNPs Influencing Changes in Blood Cholesterol Concentrations in Response to Dietary Interventions}

Recently, the availability of low-cost genetic testing kits and new bioinformatic tools has allowed significant progress in understanding the complex interplay between genetics and diet. Development of GRS, in which various SNPs information is aggregated, offers a valuable approach to explain a higher percentage of variability in blood cholesterol profiles compared to analyzing individual SNPs $[10,11]$.

In a study published in 2015, Justesen et al. investigated the effect of the interaction between GRS and lifestyle factors, including diet, on fasting serum lipid concentrations in a population-based Danish cohort comprised of 5961 male and female participants (mean age $=46.1 \mathrm{y}$, mean BMI $=26.3 \mathrm{~kg} / \mathrm{m}^{2}$ ) [55]. GRS of increased TC (74 loci), LDL-C (58 loci), or triglyceride (TG) (39 loci), and decreased HDL-C (71 loci) concentrations were built based on SNPs previously identified following GWAS of circulating fasting lipid concentrations. Dietary habits were estimated following dietary questionnaires and were classified as unhealthy, moderately healthy, and healthy. There was no significant effect of GRS and dietary habit interaction on baseline fasting serum cholesterol concentrations. The effect of specific components of the diet was not investigated.

In a secondary analysis of data from the Food4Me study, a multi-country European online randomized controlled intervention exploring the potential for personalized nutrition to enhance nutritional and health outcomes, the authors built a GRS based on 14 SNPs previously identified in GWAS of components of MetS and that showed a significant association with any component of MetS at baseline of the intervention [56]. Thus, most selected SNPs had no existing association with cholesterol metabolism and transport. They found that after 6 months of intervention, among the 1263 male and female participants (mean age $=40.8 \mathrm{y}$, mean BMI $=25.4 \mathrm{~kg} / \mathrm{m}^{2}$ ), those with a low GRS exhibited a significantly higher decrease in TC concentrations, compared to those with a high GRS (approximately $-0.1 \mathrm{mmol} / \mathrm{L}$ ), independently of Mediterranean diet adherence level.

In a secondary analysis of data from a randomized crossover study [15], members of our group demonstrated a combinatory action of three SNPs in cholesterol-related genes, where among 101 normocholesterolemic participants (age $=18-69 \mathrm{y}$ ), carriers of the genotypic combination of ABCG5 rs6720173-C, CYP7A1 rs3808607-TT, and DHCR7 rs760241-GG exhibited a maximal reduction in serum LDL-C concentrations relative to a combination of rs6720173-GG, rs3808607-G, and rs760241-A genotypes (change: $-0.37 \pm 0.12$ vs. $0.38 \pm 0.14 \mathrm{mmol} / \mathrm{L}$ ), following a blended dairy ( 3 servings $/ \mathrm{d}$ for $4 \mathrm{wk}$ ) versus dairy-free intervention [57].

In a 2019 study, Guevara-Cruz et al. investigated the effect of the interaction between a GRS and a dietary intervention on serum HDL-C concentrations in 67 Mexican adults (20-60 y) with a BMI $\geq 25 \mathrm{~kg} / \mathrm{m}^{2}$ and who had at least three out of five positive criteria for MetS [58]. The dietary intervention consisted in the consumption for 2.5 months of a diet following the National Cholesterol Education Program-Adult Treatment Panel III (NCEP-ATP III) guidelines, i.e., low in saturated fats ( $<7 \%$ energy) and cholesterol 
( $<200 \mathrm{mg} / \mathrm{d}$ ), with 20-30 g/d fiber and a 25\% reduction in total energy intake. The GRS consisted of six SNPs previously associated with MetS in GWAS, lifestyle intervention studies, and meta-analyses, and that were associated with changes in serum HDL-C concentrations following dietary intervention. The GRS built explained $42 \%$ of the variance in HDL-C concentrations following the NCEP-ATP III diet, and participants with a low GRS displayed an increase $(0.08 \mathrm{mmol} / \mathrm{L})$ in HDL-C concentrations, whereas participants with a high GRS had a decrease in HDL-C concentrations $(-0.08 \mathrm{mmol} / \mathrm{L})$. Additionally, these results were validated in an independent clinical cohort of 89 participants with MetS following a similar dietary intervention.

Collectively, these studies show that the additive effect of several SNPs, which taken individually may have small independent effects, could explain a greater part of the variability in response to a dietary intervention when combined. These data show the advantage of complex analyses including combinatory patterns of SNPs compared to the relatively low predictive value of individual SNP approaches. Although these models are promising for personalized dietary advice, the results are variable and require validation in controlled dietary interventions, including different age groups, gender, and across ethnicities.

\section{Conclusions}

This review highlights the most recent findings from studies investigating the effects of SNP-diet interactions on blood cholesterol concentrations, where 20 SNPs in 14 cholesterolrelated genes showed significant associations with various dietary intakes. This review also underscores important progress in the field, given the emerging scientific literature on the effect of combinations of SNPs on blood cholesterol concentrations in interaction with dietary intakes. This approach is likely to increase the explained variability in such a complex phenotype, and offers a valuable insight into the relationship between diet and CVD risk.

Dietary interventions designed to lower circulating cholesterol concentrations, such as those limiting intakes of trans fat from processed foods, or replacing saturated fatty acids with unsaturated fatty acids, for example, are established means for reducing the risk of developing CVD, regardless of a person's genetic makeup. Carriers of certain genotypes within cholesterol-related genes may, however, respond far better than others to a given dietary intervention, possibly leading to an improved cardiovascular health outcome. For instance, a reduction of approximately $10 \%$ in LDL-C concentrations was observed in adults carrying the genotypic combination of ABCG5 rs6720173-C, CYP7A1 rs3808607TT, and DHCR7 rs760241-GG, relative to the combination of rs6720173-GG, rs3808607G, and rs760241-A genotypes, after dairy versus dairy-free diets [57]. With evidence suggesting at least $1 \%$ reduction in CVD incidence or mortality with each $1 \%$ reduction in LDL-C or TC concentrations $[12,59,60]$, the clinical impact of such nutrigenetic studies is obvious.

Still, in addition to factors such as dietary components and population groups, it is imperative that the type of genetic mutation, whether missense, intron, or other, is also considered when assessing the potential impacts on the gene products. Of the individual SNPs reported in this review, six variants are listed by the Single Nucleotide Polymorphism Database (dbSNP) as missense variants (ABCA1 rs9282541 and rs2230806, ABCG5 rs6720173, $A B C G 8$ rs6544718, APOE rs7412, and DHCR7 rs760241), thus describing changes in single nucleotides that result in different amino acid sequences, while others include intron, upstream transcript, synonymous, 5 prime UTR, or 3 prime UTR variants. Considering the type of genetic mutation may provide some mechanistic insight into the interpretation and discussion of findings in association studies, especially when detailed reports on the molecular mechanisms of action in the field are rarely available.

Future research, including multi-site intervention trials, should take such clinical and mechanistic aspects into consideration and, furthermore, explore combinatory patterns of genetic variability in order to better understand the impact of gene-diet interactions on serum lipid profiles, and the potential cardiovascular impacts thereof. The individual SNPs 
reported in this review, and those previously reported [8], are good starting candidates to build GRS aiming at predicting changes in blood cholesterol concentrations in response to dietary interventions. As an additional tool to advance the field, the availability of artificial intelligence and machine-learning approaches for identifying panels of SNPs, which in combination could better predict an individual's lipid response to dietary interventions, offer tremendous potential [61]. The latter methods may allow a more rapid advancement of the field of personalized nutrition.

Author Contributions: Conceptualization, M.M.H.A., I.V.-V., D.J.B., P.J.H.J. and C.D.; methodology and formal analysis, M.M.H.A., I.V.-V., D.J.B., P.J.H.J. and C.D.; writing-original draft preparation, I.V.-V., M.M.H.A., and C.D.; writing-review and editing, M.M.H.A., I.V.-V., D.J.B., J.D.H., P.J.H.J. and C.D.; Project administration and funding acquisition, P.J.H.J. and J.D.H. All authors have read and agreed to the published version of the manuscript.

Funding: I.V.-V. received research funding from the International Life Sciences Institute North America (Grant 320188). Supported by the Dietary Lipids Committee, North American Branch of the International Life Sciences Institute (ILSI North America). ILSI North America is a public, nonprofit scientific foundation that provides a forum to advance understanding of scientific issues related to the nutritional quality and safety of the food supply by sponsoring research programs, educational seminars and workshops, and publications. ILSI North America receives support primarily from its industry membership. ILSI NA was not involved in the review process and provided no comments on the interpretation of the findings.

Institutional Review Board Statement: Not applicable.

Informed Consent Statement: Not applicable.

Data Availability Statement: Not applicable.

Conflicts of Interest: Disclosure I.V.-V. received stipend support from the grant received from ILSI NA. No other conflicts of interest are declared. M.M.H.A. declares no conflict of interest. D.J.B. is the Government liaison to the International Life Sciences Institute, North America Committee on Dietary Lipids. He receives no compensation in that role. J.D.H. serves as Co-Chair of the Canadian Leadership Team for ILSI NA, and currently serves as administrative lead for the research grant received from ILSI NA in support of this review. P.J.H.J. has received research grants from Nutritional Fundamentals for Health Inc., Mitacs, and the International Life Science Institute. He also owns stock in Nutritional Fundamentals for Health Inc. C.D. declares no conflict of interest.

\section{References}

1. Floris, M.; Cano, A.; Porru, L.; Addis, R.; Cambedda, A.; Idda, M.L.; Steri, M.; Ventura, C.; Maioli, M. Direct-to-Consumer Nutrigenetics Testing: An Overview. Nutrients 2020, 12, 566. [CrossRef]

2. Guasch-Ferre, M.; Dashti, H.S.; Merino, J. Nutritional Genomics and Direct-to-Consumer Genetic Testing: An Overview. Adv. Nutr. 2018, 9, 128-135. [CrossRef]

3. Price, H.C.; Nicholls, A. Primary prevention of CVD: Diet. BMJ Clin. Evid. 2014, 2014, 0219.

4. Tognon, G.; Lissner, L.; Saebye, D.; Walker, K.Z.; Heitmann, B.L. The Mediterranean diet in relation to mortality and CVD: A Danish cohort study. Br. J. Nutr. 2014, 111, 151-159. [CrossRef]

5. Adams, J.N.; Raffield, L.M.; Freedman, B.I.; Langefeld, C.D.; Ng, M.C.; Carr, J.J.; Cox, A.J.; Bowden, D.W. Analysis of common and coding variants with cardiovascular disease in the Diabetes Heart Study. Cardiovasc. Diabetol. 2014, 13, 77. [CrossRef]

6. Teslovich, T.M.; Musunuru, K.; Smith, A.V.; Edmondson, A.C.; Stylianou, I.M.; Koseki, M.; Pirruccello, J.P.; Ripatti, S.; Chasman, D.I.; Willer, C.J.; et al. Biological, clinical and population relevance of 95 loci for blood lipids. Nature 2010, 466, 707-713. [CrossRef] [PubMed]

7. Willer, C.J.; Sanna, S.; Jackson, A.U.; Scuteri, A.; Bonnycastle, L.L.; Clarke, R.; Heath, S.C.; Timpson, N.J.; Najjar, S.S.; Stringham, H.M.; et al. Newly identified loci that influence lipid concentrations and risk of coronary artery disease. Nat. Genet. 2008, 40, 161-169. [CrossRef]

8. Abdullah, M.M.; Jones, P.J.; Eck, P.K. Nutrigenetics of cholesterol metabolism: Observational and dietary intervention studies in the postgenomic era. Nutr. Rev. 2015, 73, 523-543. [CrossRef] [PubMed]

9. Vazquez-Vidal, I.; Desmarchelier, C.; Jones, P.J.H. Nutrigenetics of Blood Cholesterol Concentrations: Towards Personalized Nutrition. Curr. Cardiol. Rep. 2019, 21, 38. [CrossRef]

10. Hill, W.G.; Goddard, M.E.; Visscher, P.M. Data and theory point to mainly additive genetic variance for complex traits. PLoS Genet. 2008, 4, e1000008. [CrossRef] [PubMed] 
11. Maki-Tanila, A.; Hill, W.G. Influence of gene interaction on complex trait variation with multilocus models. Genetics 2014, 198, 355-367. [CrossRef] [PubMed]

12. Bruford, E.A.; Braschi, B.; Denny, P.; Jones, T.E.M.; Seal, R.L.; Tweedie, S. Guidelines for human gene nomenclature. Nat. Genet. 2020, 52, 754-758. [CrossRef] [PubMed]

13. Jacobo-Albavera, L.; Posadas-Romero, C.; Vargas-Alarcon, G.; Romero-Hidalgo, S.; Posadas-Sanchez, R.; Gonzalez-Salazar Mdel, C.; Carnevale, A.; Canizales-Quinteros, S.; Medina-Urrutia, A.; Antunez-Arguelles, E.; et al. Dietary fat and carbohydrate modulate the effect of the ATP-binding cassette A1 (ABCA1) R230C variant on metabolic risk parameters in premenopausal women from the Genetics of Atherosclerotic Disease (GEA) Study. Nutr. Metab. 2015, 12, 45. [CrossRef] [PubMed]

14. Liu, H.; Lin, J.; Zhu, X.; Li, Y.; Fan, M.; Zhang, R.; Fang, D. Effects of R219K polymorphism of ATP-binding cassette transporter 1 gene on serum lipids ratios induced by a high-carbohydrate and low-fat diet in healthy youth. Biol. Res. 2014, 47, 4. [CrossRef] [PubMed]

15. Abdullah, M.M.; Cyr, A.; Lepine, M.C.; Eck, P.K.; Couture, P.; Lamarche, B.; Jones, P.J. Common Variants in Cholesterol Synthesisand Transport-Related Genes Associate with Circulating Cholesterol Responses to Intakes of Conventional Dairy Products in Healthy Individuals. J. Nutr. 2016, 146, 1008-1016. [CrossRef] [PubMed]

16. Granado-Lorencio, F.; de Las Heras, L.; Millan, C.S.; Garcia-Lopez, F.J.; Blanco-Navarro, I.; Perez-Sacristan, B.; Dominguez, G. $\beta$-Cryptoxanthin modulates the response to phytosterols in post-menopausal women carrying NPC1L1 L272L and ABCG8 A632 V polymorphisms: An exploratory study. Genes Nutr. 2014, 9, 428. [CrossRef] [PubMed]

17. de Luis, D.A.; Izaola, O.; Primo, D.; Aller, R. Role of rs670 variant of APOA1 gene on lipid profile, insulin resistance and adipokine levels in obese subjects after weight loss with a dietary intervention. Diabetes Res. Clin. Pract. 2018, 142, 139-145. [CrossRef]

18. de Luis, D.; Izaola, O.; Primo, D.; Aller, R. Role of rs670 variant of APOA1 gene on metabolic response after a high fat vs. a low fat hypocaloric diets in obese human subjects. J. Diabetes Complicat. 2019, 33, 249-254. [CrossRef]

19. Noorshahi, N.; Sotoudeh, G.; Djalali, M.; Eshraghian, M.R.; Keramatipour, M.; Basiri, M.G.; Doostan, F.; Koohdani, F. APOA II genotypes frequency and their interaction with saturated fatty acids consumption on lipid profile of patients with type 2 diabetes. Clin. Nutr. 2016, 35, 907-911. [CrossRef]

20. Dominguez-Reyes, T.; Astudillo-Lopez, C.C.; Salgado-Goytia, L.; Munoz-Valle, J.F.; Salgado-Bernabe, A.B.; Guzman-Guzman, I.P.; Castro-Alarcon, N.; Moreno-Godinez, M.E.; Parra-Rojas, I. Interaction of dietary fat intake with APOA2, APOA5 and LEPR polymorphisms and its relationship with obesity and dyslipidemia in young subjects. Lipids Health Dis. 2015, 14, 106. [CrossRef]

21. Lim, H.H.; Choi, M.; Kim, J.Y.; Lee, J.H.; Kim, O.Y. Increased risk of obesity related to total energy intake with the APOA5-1131T $>$ C polymorphism in Korean premenopausal women. Nutr. Res. 2014, 34, 827-836. [CrossRef]

22. Doo, M.; Won, S.; Kim, Y. Association between the APOB rs1469513 polymorphism and obesity is modified by dietary fat intake in Koreans. Nutrition 2015, 31, 653-658. [CrossRef]

23. Shatwan, I.M.; Weech, M.; Jackson, K.G.; Lovegrove, J.A.; Vimaleswaran, K.S. Apolipoprotein E gene polymorphism modifies fasting total cholesterol concentrations in response to replacement of dietary saturated with monounsaturated fatty acids in adults at moderate cardiovascular disease risk. Lipids Health Dis. 2017, 16, 222. [CrossRef]

24. Weber, K.S.; Knebel, B.; Strassburger, K.; Kotzka, J.; Stehle, P.; Szendroedi, J.; Mussig, K.; Buyken, A.E.; Roden, M. Associations between explorative dietary patterns and serum lipid levels and their interactions with ApoA5 and ApoE haplotype in patients with recently diagnosed type 2 diabetes. Cardiovasc. Diabetol. 2016, 15, 138. [CrossRef]

25. MacKay, D.S.; Eck, P.K. CYP7A1-rs3808607 and APOE isoform associate with LDL cholesterol lowering after plant sterol consumption in a randomized clinical trial. Am. J. Clin. Nutr. 2015, 102, 951-957. [CrossRef]

26. Griffin, B.A.; Walker, C.G.; Jebb, S.A.; Moore, C.; Frost, G.S.; Goff, L.; Sanders, T.A.B.; Lewis, F.; Griffin, M.; Gitau, R.; et al. APOE4 Genotype Exerts Greater Benefit in Lowering Plasma Cholesterol and Apolipoprotein B than Wild Type (E3/E3), after Replacement of Dietary Saturated Fats with Low Glycaemic Index Carbohydrates. Nutrients 2018, 10, 1524. [CrossRef] [PubMed]

27. Garcia-Rios, A.; Alcala-Diaz, J.F.; Gomez-Delgado, F.; Delgado-Lista, J.; Marin, C.; Leon-Acuna, A.; Camargo, A.; RodriguezCantalejo, F.; Blanco-Rojo, R.; Quintana-Navarro, G.; et al. Beneficial effect of CETP gene polymorphism in combination with a Mediterranean diet influencing lipid metabolism in metabolic syndrome patients: CORDIOPREV study. Clin. Nutr. 2018, 37, 229-234. [CrossRef] [PubMed]

28. Hosseini-Esfahani, F.; Esfandiar, Z.; Mirmiran, P.; Daneshpour, M.S.; Ghanbarian, A.; Azizi, F. The interaction of cholesteryl ester transfer protein gene variations and diet on changes in serum lipid profiles. Eur. J. Clin. Nutr. 2019, 73, 1291-1298. [CrossRef]

29. Wang, Y.; Harding, S.V.; Eck, P.; Thandapilly, S.J.; Gamel, T.H.; Abdel-Aal el, S.M.; Crow, G.H.; Tosh, S.M.; Jones, P.J.; Ames, N.P. High-Molecular-Weight $\beta$-Glucan Decreases Serum Cholesterol Differentially Based on the CYP7A1 rs3808607 Polymorphism in Mildly Hypercholesterolemic Adults. J. Nutr. 2016, 146, 720-727. [CrossRef] [PubMed]

30. Zhu, X.C.; Lin, J.; Wang, Q.; Liu, H.; Qiu, L.; Fang, D.Z. Associations of lipoprotein lipase gene rs326 with changes of lipid profiles after a high-carbohydrate and low-fat diet in healthy Chinese Han youth. Int. J. Environ. Res. Public Health 2014, 11, $4544-4554$. [CrossRef]

31. Ayyappa, K.A.; Shatwan, I.; Bodhini, D.; Bramwell, L.R.; Ramya, K.; Sudha, V.; Anjana, R.M.; Lovegrove, J.A.; Mohan, V.; Radha, V.; et al. High fat diet modifies the association of lipoprotein lipase gene polymorphism with high density lipoprotein cholesterol in an Asian Indian population. Nutr. Metab. 2017, 14, 8. [CrossRef] 
32. Smith, C.E.; Van Rompay, M.I.; Mattei, J.; Garcia, J.F.; Garcia-Bailo, B.; Lichtenstein, A.H.; Tucker, K.L.; Ordovas, J.M. Dietary fat modulation of hepatic lipase variant $-514 \mathrm{C} / \mathrm{T}$ for lipids: A crossover randomized dietary intervention in Caribbean Hispanics. Physiol. Genom. 2017. [CrossRef]

33. Xu, M.; Ng, S.S.; Bray, G.A.; Ryan, D.H.; Sacks, F.M.; Ning, G.; Qi, L. Dietary Fat Intake Modifies the Effect of a Common Variant in the LIPC Gene on Changes in Serum Lipid Concentrations during a Long-Term Weight-Loss Intervention Trial. J. Nutr. 2015, 145, 1289-1294. [CrossRef]

34. Davis, H.R., Jr.; Altmann, S.W. Niemann-Pick C1 Like 1 (NPC1L1) an intestinal sterol transporter. Biochim. Biophys. Acta 2009, 1791, 679-683. [CrossRef]

35. Davis, H.R., Jr.; Basso, F.; Hoos, L.M.; Tetzloff, G.; Lally, S.M.; Altmann, S.W. Cholesterol homeostasis by the intestine: Lessons from Niemann-Pick C1 Like 1 (NPC1L1). Atheroscler. Suppl. 2008, 9, 77-81. [CrossRef]

36. Temel, R.E.; Tang, W.; Ma, Y.; Rudel, L.L.; Willingham, M.C.; Ioannou, Y.A.; Davies, J.P.; Nilsson, L.M.; Yu, L. Hepatic NiemannPick C1-like 1 regulates biliary cholesterol concentration and is a target of ezetimibe. J. Clin. Investig. 2007, 117, 1968-1978. [CrossRef] [PubMed]

37. De Smet, E.; Mensink, R.P.; Plat, J. Effects of plant sterols and stanols on intestinal cholesterol metabolism: Suggested mechanisms from past to present. Mol. Nutr. Food Res. 2012, 56, 1058-1072. [CrossRef]

38. Lee, J.Y.; Parks, J.S. ATP-binding cassette transporter AI and its role in HDL formation. Curr. Opin. Lipidol. 2005, 16, 19-25. [CrossRef] [PubMed]

39. Xu, B.; Gillard, B.K.; Gotto, A.M., Jr.; Rosales, C.; Pownall, H.J. ABCA1-Derived Nascent High-Density Lipoprotein-Apolipoprotein AI and Lipids Metabolically Segregate. Arterioscler. Thromb. Vasc. Biol. 2017, 37, 2260-2270. [CrossRef] [PubMed]

40. Acuna-Alonzo, V.; Flores-Dorantes, T.; Kruit, J.K.; Villarreal-Molina, T.; Arellano-Campos, O.; Hunemeier, T.; Moreno-Estrada, A.; Ortiz-Lopez, M.G.; Villamil-Ramirez, H.; Leon-Mimila, P.; et al. A functional ABCA1 gene variant is associated with low HDL-cholesterol levels and shows evidence of positive selection in Native Americans. Hum. Mol. Genet. 2010, 19, $2877-2885$. [CrossRef]

41. Patel, S.B.; Graf, G.A.; Temel, R.E. ABCG5 and ABCG8: More than a defense against xenosterols. J. Lipid Res. 2018, 59, 1103-1113. [CrossRef]

42. Ajagbe, B.O.; Othman, R.A.; Myrie, S.B. Plant Sterols, Stanols, and Sitosterolemia. J. AOAC Int. 2015, 98, 716-723. [CrossRef]

43. Myrie, S.B.; Mymin, D.; Triggs-Raine, B.; Jones, P.J. Serum lipids, plant sterols, and cholesterol kinetic responses to plant sterol supplementation in phytosterolemia heterozygotes and control individuals. Am. J. Clin. Nutr. 2012, 95, 837-844. [CrossRef]

44. Plat, J.; Bragt, M.C.; Mensink, R.P. Common sequence variations in ABCG8 are related to plant sterol metabolism in healthy volunteers. J. Lipid Res. 2005, 46, 68-75. [CrossRef] [PubMed]

45. Viturro, E.; de Oya, M.; Lasuncion, M.A.; Gorgojo, L.; Moreno, J.M.; Benavente, M.; Cano, B.; Garces, C. Cholesterol and saturated fat intake determine the effect of polymorphisms at ABCG5/ABCG8 genes on lipid levels in children. Genet. Med. Off. J. Am. Coll. Med. Genet. 2006, 8, 594-599. [CrossRef]

46. Bandarian, F.; Hedayati, M.; Daneshpour, M.S.; Naseri, M.; Azizi, F. Genetic polymorphisms in the APOA1 gene and their relationship with serum HDL cholesterol levels. Lipids 2013, 48, 1207-1216. [CrossRef] [PubMed]

47. Wang, S.; Smith, J.D. ABCA1 and nascent HDL biogenesis. BioFactors 2014, 40, 547-554. [CrossRef] [PubMed]

48. Bandarian, F.; Daneshpour, M.S.; Hedayati, M.; Naseri, M.; Azizi, F. Identification of Sequence Variation in the Apolipoprotein A2 Gene and Their Relationship with Serum High-Density Lipoprotein Cholesterol Levels. Iran. Biomed. J. 2016, $20,84-90$.

49. Beckstead, J.A.; Oda, M.N.; Martin, D.D.; Forte, T.M.; Bielicki, J.K.; Berger, T.; Luty, R.; Kay, C.M.; Ryan, R.O. Structure-function studies of human apolipoprotein A-V: A regulator of plasma lipid homeostasis. Biochemistry 2003, 42, 9416-9423. [CrossRef] [PubMed]

50. Lin, Y.C.; Nunez, V.; Johns, R.; Shiao, S.P. APOA5 Gene Polymorphisms and Cardiovascular Diseases: Metaprediction in Global Populations. Nurs. Res. 2017, 66, 164-174. [CrossRef]

51. Zhao, T.; Zhao, J. Association of the apolipoprotein A5 gene - $1131 \mathrm{~T}>$ C polymorphism with fasting blood lipids: A meta-analysis in 37,859 subjects. BMC Med. Genet. 2010, 11, 120. [CrossRef]

52. Agoston-Coldea, L.; Zdrenghea, D.; Pop, D.; Craciun, A.; Rusu, M.L.; Mocan, T. Apolipoproteins A-I and B-markers in coronary risk evaluation. Rom. J. Intern. Med. Rev. Roum. Med. Interne 2007, 45, 251-258.

53. Bennet, A.M.; Di Angelantonio, E.; Ye, Z.; Wensley, F.; Dahlin, A.; Ahlbom, A.; Keavney, B.; Collins, R.; Wiman, B.; de Faire, U.; et al. Association of apolipoprotein E genotypes with lipid levels and coronary risk. JAMA 2007, 298, 1300-1311. [CrossRef] [PubMed]

54. Boekholdt, S.M.; Kuivenhoven, J.A.; Hovingh, G.K.; Jukema, J.W.; Kastelein, J.J.; van Tol, A. CETP gene variation: Relation to lipid parameters and cardiovascular risk. Curr. Opin. Lipidol. 2004, 15, 393-398. [CrossRef]

55. Justesen, J.M.; Allin, K.H.; Sandholt, C.H.; Borglykke, A.; Krarup, N.T.; Grarup, N.; Linneberg, A.; Jørgensen, T.; Hansen, T.; Pedersen, O. Interactions of Lipid Genetic Risk Scores with Estimates of Metabolic Health in a Danish Population. Circ. Cardiovasc. Genet. 2015, 8, 465-472. [CrossRef]

56. San-Cristobal, R.; Navas-Carretero, S.; Livingstone, K.M.; Celis-Morales, C.; Macready, A.L.; Fallaize, R.; O’Donovan, C.B.; Lambrinou, C.P.; Moschonis, G.; Marsaux, C.F.M.; et al. Mediterranean Diet Adherence and Genetic Background Roles within a Web-Based Nutritional Intervention: The Food4Me Study. Nutrients 2017, 9, 1107. [CrossRef] [PubMed] 
57. Abdullah, M.M.H.; Eck, P.K.; Couture, P.; Lamarche, B.; Jones, P.J.H. The combination of single nucleotide polymorphisms rs6720173 (ABCG5), rs3808607 (CYP7A1), and rs760241 (DHCR7) is associated with differing serum cholesterol responses to dairy consumption. Appl. Physiol. Nutr. Metab. Physiol. Appl. Nutr. Metab. 2018, 43, 1090-1093. [CrossRef]

58. Guevara-Cruz, M.; Medina-Vera, I.; Flores-López, A.; Aguilar-López, M.; Smith, C.E.; Parnell, L.D.; Lee, Y.C.; Lai, C.Q.; Tovar, A.R.; Ordovás, J.M.; et al. Development of a Genetic Score to Predict an Increase in HDL Cholesterol Concentration After a Dietary Intervention in Adults with Metabolic Syndrome. J. Nutr. 2019, 149, 1116-1121. [CrossRef] [PubMed]

59. Mihaylova, B.; Emberson, J.; Blackwell, L.; Keech, A.; Simes, J.; Barnes, E.H.; Voysey, M.; Gray, A.; Collins, R.; Baigent, C. The effects of lowering LDL cholesterol with statin therapy in people at low risk of vascular disease: Meta-analysis of individual data from 27 randomised trials. Lancet 2012, 380, 581-590. [CrossRef]

60. Robinson, J.G.; Smith, B.; Maheshwari, N.; Schrott, H. Pleiotropic effects of statins: Benefit beyond cholesterol reduction? A meta-regression analysis. J. Am. Coll. Cardiol. 2005, 46, 1855-1862. [CrossRef] [PubMed]

61. Shameer, K.; Johnson, K.W.; Glicksberg, B.S.; Dudley, J.T.; Sengupta, P.P. Machine learning in cardiovascular medicine: Are we there yet? Heart 2018, 104, 1156-1164. [CrossRef] [PubMed] 